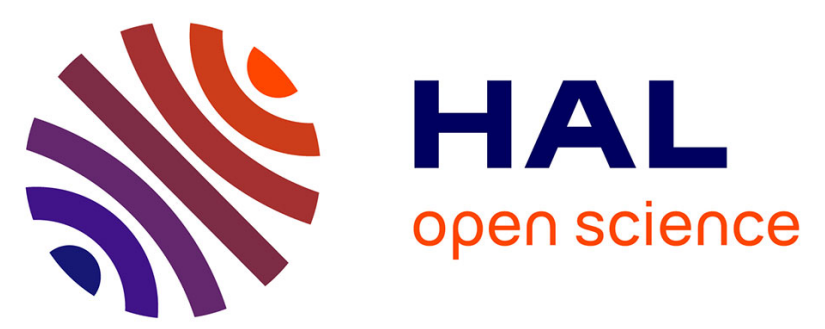

\title{
Natural killer cells recruited into lymph nodes inhibit alloreactive T-cell activation through perforin-mediated killing of donor allogeneic dendritic cells.
}

Sophie Laffont, Cyril Seillet, John Ortaldo, Jérôme D. Coudert, Jean-Charles Guéry

\section{- To cite this version:}

Sophie Laffont, Cyril Seillet, John Ortaldo, Jérôme D. Coudert, Jean-Charles Guéry. Natural killer cells recruited into lymph nodes inhibit alloreactive T-cell activation through perforin-mediated killing of donor allogeneic dendritic cells.: NK-mediated allogeneic DC killing in lymph nodes. Blood, 2008, 112 (3), pp.661-71. 10.1182/blood-2007-10-120089 . inserm-00306011

\section{HAL Id: inserm-00306011 https://www.hal.inserm.fr/inserm-00306011}

Submitted on 25 Jul 2008

HAL is a multi-disciplinary open access archive for the deposit and dissemination of scientific research documents, whether they are published or not. The documents may come from teaching and research institutions in France or abroad, or from public or private research centers.
L'archive ouverte pluridisciplinaire HAL, est destinée au dépôt et à la diffusion de documents scientifiques de niveau recherche, publiés ou non, émanant des établissements d'enseignement et de recherche français ou étrangers, des laboratoires publics ou privés. 
Natural killer cells recruited into lymph nodes inhibit alloreactive $T$ cell activation through perforin-mediated killing of donor allogeneic dendritic cells.

Short title: NK-mediated allogeneic DC killing in lymph nodes

Sophie Laffont ${ }^{* 1}$, Cyril Seillet ${ }^{* 1}$, John Ortaldo ${ }^{\S}$, Jérôme D. Coudert ${ }^{* 1}$, and Jean-Charles Guéry* ${ }^{\dagger 2}$

*INSERM, U563, Centre de Physiopathologie de Toulouse Purpan, Toulouse, F-31300 France; ${ }^{\dagger}$ Université Paul-Sabatier, Toulouse, F-31400 France; ${ }^{8}$ Laboratory of Experimental Immunology, National Cancer Institute-Frederick, Center for Cancer Research, Frederick, MD 21702, USA.

This work was supported by a grant from Etablissement Français des Greffes and by institutional grants from INSERM.

${ }^{1} \mathrm{SL}, \mathrm{CS}$ and JDC were supported by fellowships from the Ministère de l'Education Nationale de la Recherche et des Technologies, and also from l'Association pour la Recherche sur le Cancer (ARC) for SL and from la Fondation pour la Recherche Médicale (FRM) for JDC.

SL present address: Sir William Dunn School of Pathology, University of Oxford, United Kingdom. JDC present address: Centre for Experimental Immunology, Lions Eye Institute, Nedlands, Western Australia 6009, Australia.

${ }^{2}$ Address correspondence to Dr. Jean-Charles Guéry. INSERM U563, CHU Purpan, Place du Dr Baylac, BP 3028, 31024 Toulouse Cedex 3 France. Tel. 33-5 6274 83 78, Fax. 33-5 62 744558

e-mail: Jean-Charles.Guery@toulouse.inserm.fr

Total word counts : 4969

Abstract word counts: 197

Reference count: 40

Scientific heading: Immunobiology

\section{Summary}


Natural killer (NK) cell alloreactivity is exploited in bone marrow transplantation to improve clinical outcome. Likewise, in solid organ transplantation, it has been recently shown that recipient NK cells may limit alloreactive $\mathrm{T}$ cell responses through their capacity to prevent the persistence of graft-derived allogeneic dendritic cells (DCs). In a model of CD4 ${ }^{+}$ $\mathrm{T}$ cell mediated allogeneic skin graft rejection, we show that the absence of host NK cell alloreactivity was characterized by enhanced expansion of alloreactive effector $T$ lymphocytes, including Th2 cells, and massive eosinophilic infiltrates in the rejected tissues. In $\mathrm{CD}^{+} \mathrm{T}$ cell-deficient $\mathrm{C} 57 \mathrm{BL} / 6\left(\mathrm{H}-2^{\mathrm{b}}\right)$ recipients injected with allogeneic BALB/c $\left(\mathrm{H}-2^{\mathrm{d}}\right)$ DCs, we demonstrated that NK cells expressing the H-2D ${ }^{d}$-specific Ly49D activating receptor were implicated in the regulation of alloreactive $\mathrm{CD}^{+} \mathrm{T}$ cell responses. Moreover, we showed that Ly49D ${ }^{+}$CD127 $7^{-} \mathrm{NK}$ cells were recruited within DC draining lymph nodes and rapidly eliminated allogeneic $\mathrm{H}-2^{\mathrm{d}}$ DCs through the perforin pathway. In normal mice, we further demonstrated that NK cells by quickly eliminating allogeneic DCs strongly inhibited alloreactive $\mathrm{CD}^{+} \mathrm{T}$ cell responses. Thus, NK cells act as early regulators of alloreactive $\mathrm{T}$ cell priming in allotransplantation through their capacity to kill allogeneic DCs in draining lymph nodes. 


\section{Introduction}

NK cells are a major component of the innate immune system and are capable of killing target cells without prior immunization ${ }^{1}$. Activation of NK cells results from the balance between the engagement of complex families of inhibitory and activatory receptors specific for MHC I molecules and various others ligands ${ }^{2,3}$. Inhibitory receptors encompass several families of cell surface molecules, such as Ly 49 and CD94/NKG2 receptors in mouse, that recognize self-MHC class Ia molecules and transmit intracellular signals preventing NK cell activation and target cell lysis ${ }^{2,3}$. Activating receptors recognize MHC class I-like molecules and other undefined ligands and trigger lysis and cytokine production ${ }^{3}$. Engagement of an excess of inhibitory receptors aborts the activating signaling cascades. Consequently in allotransplantation settings, interaction with fully mismatched allogeneic cells, lacking self MHC I molecules, leads to unopposed activating signals and NK cell activation characterized by target cell killing and cytokine release ${ }^{4}$.

Their ability to distinguish allogeneic cells from self and their potent cytolytic effector function make NK cells relevant to allogeneic bone marrow transplantation ${ }^{5}$. However, their role in the rejection of organ grafts has been difficult to highlight and is still a matter of debate ${ }^{6}$. While some studies have suggested that NK cells do not participate to rejection of solid organ transplants ${ }^{7,8}$, it has been recently shown that, in certain models, NK cells could function as potent effector cells to promote allograft rejection ${ }^{9}$ or to trigger allograft vasculopathy ${ }^{10}$. A dominant role of NK cells in fully allogeneic cardiac transplant rejection was reported in CD28-deficient recipients with impaired T-cell costimulatory functions. This effect of NK cells was attributed to their capacity to promote allogeneic DC maturation and subsequent alloreactive $\mathrm{T}$ cell activation, overcoming the CD28-deficiency ${ }^{9,11}$. This hypothesis, however, has been recently challenged by the demonstration, that in normal mice, 
host NK cells were implicated in the induction of islet allograft tolerance through costimulation blockade ${ }^{12}$. Although the mechanisms were not defined, it was shown that NK cell-derived perforin (pfp) was required for tolerance induction ${ }^{12}$. Likewise, a prominent role for NK cells has been recently reported in a skin-graft model of transplantation tolerance induced by co-stimulator blockade ${ }^{13}$. Interestingly, it was shown that host NK cells were able to kill graft-derived APCs, including DCs, thereby preventing excessive priming of alloreactive $\mathrm{T}$ cells in lymphoid and non-lymphoid tissues. These data indicate that in the absence of NK cells, allogeneic DCs can persist in the host and enhance T cell priming thereby hindering the induction of tolerance to these highly immunogenic transplants ${ }^{13}$. This observation is in agreement with our previous works showing that recognition of allogeneic DCs by host NK cells strongly affected the magnitude of allospecific $\mathrm{CD} 4^{+} \mathrm{T}$ cell responses as well as their cytokine secretion profiles ${ }^{14}$.

Altogether these observations suggested that host NK cells, through their ability to recognize and kill cells expressing allogeneic MHC class I molecules, might limit the persistence of donor-derived DCs, thereby inhibiting alloreactive $\mathrm{T}$ cell priming through the direct pathway ${ }^{13,14}$. As we recently showed that host allospecific CTLs can rapidly eliminate semi-allogeneic DCs in lymph nodes ${ }^{15}$, we have used CD8 $\alpha$-deficient mice as recipients ${ }^{14}$. In this model, we examined the site and the mechanism of allogeneic DC elimination by host NK cells, and its consequences on alloreactive $\mathrm{CD}^{+}$and $\mathrm{CD} 8^{+} \mathrm{T}$ cell responses. 


\section{Materials and Methods}

Mice

BALB/c $\left(\mathrm{H}-2^{\mathrm{d}}\right)$ and C57BL/6 (B6) $\left(\mathrm{H}-2^{\mathrm{b}}\right)$ mice were purchased from Centre d'Elevage R. Janvier (Le Genest St Isle, France). $\beta_{2} \mathrm{~m}^{-/-}$mice on the BALB/c background were generated as previously described ${ }^{14}$. B6 CD8 $\alpha^{-/ /}, \mathrm{B} 6$ perforin-deficient $\left(\mathrm{pfp}^{-/}\right)$and $\mathrm{B} 6 \mathrm{IL}-12 \mathrm{R} \beta 2^{-/-}$mice Supprimé : and were initially obtained from The Jackson Laboratory (Bar Harbor, ME, United States of

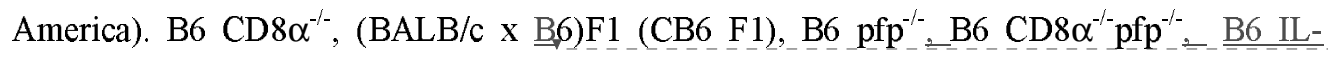
$12 \mathrm{R} \beta 2^{-/-}$and $\mathrm{BALB} / \mathrm{c} \beta_{2} \mathrm{~m}_{-}^{-/-}$mice were bred and maintained in our specific pathogen-free Supprimé : C57BL/ Supprimé : and animal facility.

\section{In vivo mAb treatment}

For in vivo NK cell-depletion, the anti-NK1.1 PK136 mouse IgG2a mAb (HB 191, American Type Culture Collection (ATCC), Manassas, VA, USA) was purified from ascites fluid by caprylic acid precipitation. Mice were injected intraperitonealy with $200 \mu \mathrm{g}$ of PK136 the day before and the day of immunization. For specific NK cell subset depletion, $100 \mu \mathrm{g}$ of the anti-Ly49D 4E5 rat IgG2a mAb or $100 \mu \mathrm{g}$ of anti-Ly49A/D $12 \mathrm{~A} 8$ rat IgG2a mAb were injected at day -1 and 0 of the experiment. For in vivo $\mathrm{CD}^{+} \mathrm{T}$ cell depletion, mice were injected with anti-CD8 $\alpha$ 53-6.72 rat IgG2a (TIB-105, ATCC) as previously shown ${ }^{15}$. For Lselectin blockade experiments, mice received $100 \mu \mathrm{g}$ of anti-CD62L monoclonal antibody Mel-14 three hours before DC injection.

\section{Skin grafting and histological studies}

Skin grafts were performed as previously described ${ }^{14}$. For histological analysis, skin grafts were fixed with formol for 24 hours at $37^{\circ} \mathrm{C}$ and then tissue sections were stained with 
hematoxylin and eosin, after paraffin embedding. The percentage of eosinophils among infiltrating mononuclear cells was determined in at least three fields per graft as previously shown ${ }^{15} \cdot$.

\section{Bone-marrow derived-dendritic cells}

Mouse bone marrow cells were cultured in complete culture medium at $2 \times 10^{6}$ in bacteriological petri dish (Greiner Bio-one, Frickenhausen, Germany) supplemented with supernatant of J558L cells transfected with a plasmid expressing the murine granulocyte macrophage-colony stimulating factor (GM-CSF). The method used here was adapted from a protocol previously described ${ }^{16}$. DC preparations ( $\left(>0 \%\right.$ of $\mathrm{CD} 11 \mathrm{c}^{\mathrm{pos}}$ cells) were used at day 8-9 of culture to immunize mice subcutaneously into the hind footpads.

Supprimé : Eosinophil are easily identified by their plurilobed nuclei and the intense staining of their cytoplasm by eosin

\section{T cell assays}

$\mathrm{CD}^{+} \mathrm{T}$ cells from popliteal and inguinal lymph nodes of DC-immunized mice or inguinal and axillary lymph nodes draining the skin graft were purified by negative selection as previously described ${ }^{15} . \mathrm{CD}^{+} \mathrm{T}$ cells (purity $>90 \%$ ) were cultured with irradiated allogeneic splenocytes in HL-1 synthetic medium (Cambrex, Walkersville, MD). Supernatants were collected after $72 \mathrm{~h}$ for cytokine analysis. IFN- $\gamma$ and IL-4 were quantified by two sites sandwich ELISA as previously described ${ }^{17}$. For $\mathrm{T}$ cell proliferation assays, cell cultures were pulsed the last 8 hours of culture with $\left.1 \mu \mathrm{Ci}(37 \mathrm{KBq}){ }^{3} \mathrm{H}\right] \mathrm{TdR}(40 \mathrm{Ci} / \mathrm{nmol}$; the Radiochemical Centre, Amersham, United Kingdom). Incorporation of $\left[^{3} \mathrm{H}\right] \mathrm{TdR}$ was measured by an MicroBeta TriLux luminescence counter (Perkin Elmer, Waltham, MA, USA). 


\section{Flow cytometry}

For the analysis of intracellular cytokine synthesis, $\mathrm{CD} 4^{+} \mathrm{T}$ cells were cultured in complete medium with T-cell depleted allogeneic BALB/c splenocytes for 8 hours in presence of anti-CD28 mAb (3 $\mu \mathrm{g} / \mathrm{ml}$, e-Bioscience, San Diego, CA) as previously described 15. Brefeldin A (Sigma-Aldrich) was added at $10 \mu \mathrm{g} / \mathrm{ml}$ for the last $4 \mathrm{~h}$ of culture. The following mAbs purchased from Pharmingen (San Diego, CA) were used: anti-CD4, antiSupprimé : M CD69 and anti-IL-4 (11B11 clone). For NK cell phenotyping, the following fluorochromeconjugated mAbs (Pharmingen) were used: anti-TCR $\beta$, anti-NK1.1, anti-DX5, anti-CD11b, anti-CD69, anti-CD127 and anti-Ly49D (4E5 clone). Intracellular staining for IFN- $\gamma$ was performed on ex vivo isolated lymph node cells as described elsewhere ${ }^{18}$.

\section{DC migration assay}

For in vivo cytotoxic assay, B6 and BALB/c DCs were labeled with either $1 \mu \mathrm{M}$ or 10 $\mu \mathrm{M}$ of carboxyfluorescein diacetate succinimidyl ester (CFSE; Molecular Probe, Leiden, The Netherlands) as described ${ }^{15}$ and then injected subcutaneously into the hind footpads. At indicated times, draining popliteal lymph node were removed and digested with collagenase IV (Sigma-Aldrich) at $400 \mathrm{U} / \mathrm{ml}$ for $30 \mathrm{~min}$ at $37^{\circ} \mathrm{C}$. The following fluorochrome-conjugated monoclonal antibodies (mAbs) were used: anti-CD11c (PharMingen, San Diego, CA) and Supprimé : containing FCS $1 \%$, normal mouse serum $3 \%$, normal rat serum $3 \%, 5$ $\mu \mathrm{g} / \mathrm{ml} 2.4 \mathrm{G} 2$ in $\mathrm{PBS}$. anti-MHC class II (e-Bioscience, San Diego, CA). Cells were gated on CD11 $\mathrm{c}^{\mathrm{pos}}, \mathrm{MHC} \mathrm{II}^{\mathrm{high}}$ and $\mathrm{CFSE}^{\mathrm{pos}}$ cells that represent around $2-4 \%$ of $\mathrm{CD} 11 \mathrm{c}^{\mathrm{pos}} \mathrm{MHC} \mathrm{II}^{\text {high }} \mathrm{DCs}$ in lymph nodes. Percentages of allogeneic target $\mathrm{BALB} / \mathrm{c}$ cells were normalized to control syngeneic B6 cells. Supprimé : $\mathrm{CFSE}^{\text {high }}$ Supprimé : $\mathrm{CFSE}^{\text {low }}$ All cytometry data were collected on a FACSCalibur (Becton Dickinson, Mountain View, CA) and analyzed using the FlowJo software (Tree Star, Olten, Switzerland). 


\section{Confocal microscopy}

DCs from indicated origins were labeled with $10 \mu \mathrm{M}$ of CFSE or $10 \mu \mathrm{M}$ of (5-(and-6)-((4-chloromethyl)benzoyl)amino) tetramethylrhodamine (CMTMR; Molecular probes) as Supprimé : ( indicated by manufacturer. Depending on the experiment, CMTMR-labeled BALB/c cells alone or a mixture of $1 \times 10^{6} \mathrm{CFSE}-$ labeled BALB/c DCs and $1 \times 10^{6} \mathrm{CMTMR}-$ labeled B6 DCs were injected subcutaneously into the hind footpads of recipient mice. At indicated times after injection, popliteal draining lymph nodes were harvested and prepared for confocal microscopy analysis as previously described ${ }^{15}$. Cryostat sections $(10 \mu \mathrm{m})$ were stained with unconjugated anti-peripheral lymph node addressin (PNAd) mAb (Meca-79, PharMingen) and anti-B220 mAb (RA36B2, Pharmingen). PNAd and B220 were revealed with AlexaFluor647 goat anti-rat Ig antibodies (Molecular Probes). In some experiments, frozen sections of lymph nodes were fixed with acetone, and stained with goat anti-NKp46 antibodies (R\&D Systems, Mineapolis, MN, USA), followed by donkey anti-goat antibodies conjugated to Alexa 488 or Alexa 633 (Invitrogen, Oregon, USA). Sections were analyzed by using a LSM 510 confocal microscope and acquisition system (Carl Zeiss, Jena, Germany) equipped with a 10X/1.4 objective lens. Images were then processed with Adobe Photoshop CS2 software version 8.0.1 (Adobe systems, San Jose, CA)

\section{Statistical analysis}

Differences between variables were evaluated with by the Student's $t$-test using Prism GraphPad software (San diego, CA).

Supprimé : . Supprimé : đ Supprimé : đ Supprimé : s 


\section{Results}

Effect of host NK cell activation on allospecific $\mathrm{CD4}^{+} \mathrm{T}$ cell development and skin allograft rejection in vivo

We previously showed that activation of host NK cells by allogeneic DCs immunization or skin graft transplantation, in recipient mice lacking $\mathrm{CD} 8^{+} \mathrm{T}$ cells, resulted in diminished allospecific Th cell responses associated with the development of effector Th cells producing IFN- $\gamma$ but no type- 2 cytokines. NK cell elimination was sufficient to restore strong alloreactive $\mathrm{CD}^{+} \mathrm{T}$ cell priming and to promote $\mathrm{Th} 2$ cell development ${ }^{14}$. A typical experiment is presented in Figure 1, where CD8-deficient B6 mice, depleted or not of NK cells by anti-NK1.1 treatment, were grafted with fully allogeneic BALB/c skin. At day 8, $\mathrm{CD}^{+} \mathrm{T}$ cells were purified from draining lymph nodes and stimulated in vitro with allogeneic $\mathrm{BALB} / \mathrm{c}$ APCs. In agreement with previous works ${ }^{14}, \mathrm{CD}^{+} \mathrm{T}$ cells from NK-depleted mice proliferated vigorously and produced large amounts of IFN- $\gamma$ and IL-4. By contrast, in presence of NK cells, priming with allogeneic skin graft induced a modest proliferative response of alloreactive $\mathrm{CD}^{+} \mathrm{T}$ cells that produced some IFN- $\gamma$ but no IL-4 (Figure 1B, C). Histological analysis of rejected allogeneic BALB/c skin grafts showed massive eosinophil infiltrates in NK cell-depleted mice confirming the Th2-bias of the alloreactive response (Figure 1D). As a control to prevent NK cell activation by donor allograft, we used (BALB/c $\mathrm{x}$ B6)F1 mice that express recipient MHC I molecules as skin graft donors. As expected, in this combination skin graft rejection was associated with strong tissue eosinophilia (Figure 1D) and alloreactive Th2 cell priming (data not shown). Taken together, our data show that in absence of $\mathrm{NK}$ cell activation, $\mathrm{CD} 4^{+} \mathrm{T}$ cell mediated graft rejection is characterized by enhanced expansion of alloreactive effector $\mathrm{T}$ lymphocytes, including Th2 cells probably responsible for the massive eosinophilic infiltration in rejected skin allografts. 
$\mathrm{Ly}_{49 \mathrm{D}}{ }^{+} \mathrm{NK}$ cells regulate alloreactive $\mathrm{CD}^{+} \mathrm{T}$ cell priming and polarization in response to allogeneic H-2 ${ }^{\mathrm{d}}$ DCs

We next thought to determine the subsets of host NK cells that are required for the regulation of $\mathrm{H}-2^{\mathrm{d}}$-specific $\mathrm{CD}^{+} \mathrm{T}$ cell responses in CD8-deficient B6. As alloreactive $\mathrm{T}$ cell response in this model of skin graft rejection is likely to be induced by donor DCs that migrate to the draining lymph nodes ${ }^{19}$, CD8-deficient B6 mice were immunized with allogeneic BM-DCs from BALB/c mice. In this experimental setting, NK cell depletion induced alloreactive $\mathrm{CD}^{+} \mathrm{T}$ cell priming in allogeneic DC-immunized but not naive mice (Figure $\mathrm{S} 1$ ). As it has been reported in $\mathrm{H}-2^{\mathrm{d}}$ bone marrow transplant rejection ${ }^{20}$, we hypothesized that the regulatory role of NK cells was mediated by a subset of NK cells expressing Ly49D activating receptor specific for $\mathrm{H}-2 \mathrm{D}^{\mathrm{d}} \mathrm{MHC}$ class I molecules expressed on allogeneic DCs ${ }^{21,22}$. As shown in Figure 2A, administration of anti-Ly49A/D (12A8) mAb enhanced $\mathrm{H}-2^{\mathrm{d}}$-specific proliferative $\mathrm{CD} 4^{+} \mathrm{T}$ cell response and induced the development of effector Th cells producing not only IFN- $\gamma$, but also IL-4. In contrast, allogeneic DC immunization of control $\mathrm{B} 6 \mathrm{CD}^{-/-}$mice induced a moderate priming of alloreactive $\mathrm{CD} 4^{+} \mathrm{T}$ cell responses. This was confirmed by analyzing the frequency of $\mathrm{H}-2^{\mathrm{d}}$-specific $\mathrm{Th} 2$ cells by intracellular cytokine staining. IL-4 producing $\mathrm{CD} 69^{+} \mathrm{CD} 4^{+} \mathrm{T}$ cells specific for $\mathrm{H}-2^{\mathrm{d}} \mathrm{MHC}$ class II molecules were detected at similar frequency in anti-NK.1.1 and anti-Ly49D/Atreated mice and represented around $1 \%$ of total $\mathrm{CD}^{+} \mathrm{T}$ lymphocytes. The frequency of IL- $4^{+}$ $\mathrm{CD}^{+} \mathrm{T}$ cells was below $0.02 \%$ when $\mathrm{T}$ cells were cultured with syngeneic APCs (not shown). In NK sufficient mice immunized with allogeneic DCs (Figure 2B), the frequency of IL-4producing $\mathrm{CD}^{+} \mathrm{T}$ cells was either very low $(<0.2 \%)$ or undetectable (not shown). Since

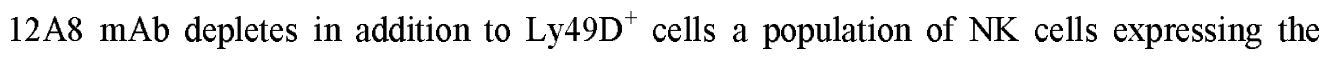
Ly49A inhibitory receptor, we evaluated the effect of selective depletion of Ly49D using the $4 \mathrm{E} 5 \mathrm{mAb}$. In the spleen and lymph nodes of $12 \mathrm{~A} 8$ - or $4 \mathrm{E} 5$-treated mice ${ }_{2}$ we noticed a slight 
reduction of NK cell numbers and a complete disappearance of NK cells expressing high levels of Ly49D (Figure S2). This selective elimination of Ly49D-bearing NK cells had almost similar effect as complete NK cell depletion, by restoring strong alloreactive $\mathrm{CD} 4^{+} \mathrm{T}$ cell priming and expansion of IFN- $\gamma$ and IL-4-producing effector Th cells (Figure 2C). We also evaluated the effect of Ly49D ${ }^{+} \mathrm{NK}$ cell-depletion on $\mathrm{CD}^{+} \mathrm{T}$ cell responses induced in B6 $\mathrm{CD}^{-/}$mice immunized with MHC class I-deficient BALB/c DCs. As shown in Figure 2D, B2m-deficient BALB/c DCs were unable to prime alloreactive $\mathrm{CD} 4^{+} \mathrm{T}$ cell responses in both control and anti-Ly49D-treated mice. By contrast, when recipient mice were depleted of their whole NK cell compartment using anti-NK1.1 mAb, a potent alloreactive $\mathrm{H}-2^{\mathrm{d}}$-specific CD4 ${ }^{+}$ $\mathrm{T}$ cell responses developed characterized by a strong production of type- 1 and type- 2 effector cytokines (Figure 2D). Thus, in 4E5-treated mice, the remaining Ly49D- NK cells were still efficient in inhibiting alloreactive $\mathrm{CD}^{+} \mathrm{T}$ cell priming by allogeneic $\beta 2 \mathrm{~m}$-deficient BALB/c DCs. Similar results were obtained using anti-Ly49D/A mAb 12A8 (not shown). Altogether, these data indicate that the failure of allogeneic $\mathrm{H}-2^{\mathrm{d}}$ DCs to efficiently prime alloreactive CD4 $\mathrm{T}$ cells is a consequence of the activation of $\mathrm{H}-2 \mathrm{D}^{\mathrm{d}}$-specific $\mathrm{Ly} 49 \mathrm{D}^{+} \mathrm{NK}$ cells. These results also rule out any role for NKT cells as Ly49D molecules have indeed been reported to be exclusively expressed on NK cells ${ }^{23-25}$.

\section{Increased recruitment and activation of host NK cells in allogeneic DC draining lymph nodes}

Having shown that $\mathrm{Ly} 49 \mathrm{D}^{+} \mathrm{NK}$ cells regulate $\mathrm{CD} 4^{+} \mathrm{T}$ cell priming in response to allogeneic BALB/c DCs, we next examined the recruitment and activation status of host NK cells in DC-draining lymph nodes 24 hours after immunization. As shown in Figure 3A, the frequency of NK1.1 $1^{+} \mathrm{TCR} \beta^{-} \mathrm{NK}$ cells was increased up to six-fold in allogeneic DC-draining lymph nodes as compared to control lymph nodes from non-immunized mice. Immunization 
with syngeneic B6 DCs also induced the recruitment of NK cells to draining lymph nodes, although to a lesser extent than fully allogeneic BALB/c DCs. Lymph node cellularity was equivalently enhanced in mice primed with syngeneic or allogeneic BALB/c DCs with similar proportion of $\mathrm{T}$ and $\mathrm{B}$ cells (not shown). NK cell recruitment was associated with an increased frequency of NK cells expressing the activation markers CD69 (Figure 3B) or $\mathrm{CD} 11 \mathrm{~b}$ (Figure 3C) in allogeneic DC-draining lymph nodes as compared to lymph nodes from control or syngeneic DC-immunized mice. Likewise, the frequency of IFN- $\gamma$-secreting $\mathrm{CD} 69^{+} \mathrm{NK} 1.1^{+} \mathrm{TCR} \beta^{-} \mathrm{NK}$ cells increased from $0.2 \%$ to $3-4 \%$ at 24 hours after immunization (Figure 3D). These data collectively demonstrate that upon immunization with allogeneic DCs, NK cells harboring an activated phenotype are rapidly recruited to draining lymph nodes.

\section{Host Ly49D ${ }^{+} \mathrm{NK}$ cells are responsible for allogeneic DC elimination in vivo}

Thereafter, we investigated whether this rapid afflux of alloreactive NK cells could have an impact on allogeneic DC elimination in draining lymph nodes. We therefore monitored the accumulation and/or persistence of BALB/c DCs in the recipient lymph nodes. To this end, $\mathrm{B} 6 \mathrm{CD}^{-/-}$mice were immunized s.c. with equal numbers of syngeneic $\mathrm{B} 6$ and allogeneic BALB/c DCs respectively labeled with low and high concentrations of CFSE dye. Histograms in Figure 4A are representative of CFSE-labeled DC profiles obtained at 48 hours from untreated and anti-NK1.1 treated $\mathrm{B} 6 \mathrm{CD}^{-/-}$mice. As shown in Figure 4B, depletion of host NK cells was associated with an increase in allogeneic DC numbers in draining lymph nodes from 48 to 72 hours after immunization. Next, to determine whether Ly49D ${ }^{+} \mathrm{NK}$ cells were implicated in the inhibition of allogeneic DC persistence, CD8-deficient B6 mice were treated or not with anti-NK.1.1 or anti-Ly49D mAb and then immunized with the same DC mixture as before. We found that allogeneic DC persistence was similarly increased in mice 
depleted of $\mathrm{NK} 1.1^{+}$or $\mathrm{Ly} 49 \mathrm{D}^{+} \mathrm{NK}$ cells suggesting that allogeneic $\mathrm{DC}$ elimination was mediated by a subset of $\mathrm{NK}$ cells bearing the $\mathrm{H}-2 \mathrm{D}^{\mathrm{d}}$-specific Ly49D activating receptor (Figure 4C and Figure S3).

Then, in order to directly visualize allogeneic DC persistence in draining lymph nodes in absence of host $\mathrm{NK}$ cells, we performed confocal microscopy analysis. $\underline{\mathrm{B} 6 \mathrm{CD} 8^{-/-} \text {mice }}$ were injected with BALB/c DCs labeled with CMTMR (red). As shown in Figure $4 \underline{\mathrm{D}}$ and $\mathrm{E}$, allogeneic DCs were present at high numbers only in NK-depleted mice._NK cells were then visualized by NKp46-staining ${ }^{26}$. Consistent with previous works ${ }^{18,26}$, NK cells were found in the paracortex and the medulla of lymph nodes of control but not anti-NK1.1-treated mice (Figure 4E), and therefore co-localized in the same lymph node areas as DCs (see Figure S5 and S7). We next determined the kinetics of DC elimination in the draining lymph nodes by injecting $\mathrm{B} 6 \mathrm{CD}^{-/-}$mice with a mixture of $\mathrm{CFSE}-$ labeled BALB/c DCs (green) and CMTMR-labeled B6 DCs (red). Data in Figure $4 \mathrm{~F}$ show that allogeneic DC numbers were not affected by the presence or absence of NK cells at early time point (18 hours). By contrast, alterations in BALB/c DC numbers were evident at 24 to 48 hours in control mice as compared to NK-depleted hosts. Altogether, these data show that allogeneic DCs fail to accumulate and to persist in the presence of NK cells, and suggest that NK cells expressing the Ly49D activating receptor participate in a large extent to the rapid elimination of allogeneic DCs within the draining lymph nodes.

\section{Recently recruited NK cells are responsible of allogeneic DC killing}

The above data indicated that the rapid afflux of NK cells in the draining lymph nodes was associated with the elimination of donor-derived allogeneic DCs. We therefore investigated whether newly recruited NK cells rather than resident NKs were directly implicated in allogeneic DC killing. To assess this point, we performed L-selectin-blocking 
experiments as some reports have shown that entry of blood NK cells into lymph nodes was mediated through HEVs (high endothelial venules) in a CD62L-dependent manner ${ }^{18,27,28}$. B6 $\mathrm{CD}^{-/}$mice were injected with anti-CD62L blocking $\mathrm{mAb}$ and immunized 3 hours later with allogeneic DCs. At 48 hours after DC injection, draining lymph nodes were harvested and analyzed for the presence of NK cells and allogeneic DCs. As expected, the number of NK cells recruited into DC-draining lymph nodes was reduced by $90 \%$ by injecting anti-CD62L $\mathrm{mAb}$ (Figure 5A). We looked at the repartition of two NK cell subsets, the newly described thymic NK cells expressing CD127 (IL-7 receptor $\alpha$ ) ${ }^{29}$ and the conventional CD127 NK subset. We found that the CD62L blockade preferentially affected the conventional subset with a marked decrease in the percentage of CD127 NK cells expressing Ly49D (Figure 5B). Blockade of blood-borne NK cell migration into the lymph nodes prevented allogeneic DC killing, as efficiently as NK cell depletion (Figure 5C). These results strongly suggested that $\mathrm{CD}^{2} 27^{-} \mathrm{Ly}_{49 \mathrm{D}^{+}} \mathrm{NK}$ cells recruited from the blood into the draining lymph nodes were responsible for allogeneic DC elimination, rather than lymph node-resident NK cells.

\section{Perforin-mediated killing is critical for the elimination of allogeneic DCs by host NK cells in vivo}

To gain insight into the mechanisms underlying allogeneic DC elimination by NK cells, we analyzed DC persistence in perforin-deficient mice, as perforin is a critical molecule in the cytolytic function of NK cells ${ }^{30}$. Groups of B6 WT and B6 $\mathrm{pfp}^{-/-}$mice were all depleted of $\mathrm{CD}^{+} \mathrm{T}$ lymphocytes by antibody treatment, as we and others recently showed that $\mathrm{CTL}$ can rapidly kill semi-allogeneic DCs within the draining lymph nodes ${ }^{15,31}$. Groups of mice received in addition anti-NK1.1 mAb prior to injection with equal numbers of allogeneic BALB/c and syngeneic B6 DCs differentially labeled with CFSE as above (Figure 6A and Figure S4A). We found that allogeneic DCs failed to accumulate unless NK cells were 
previously depleted. In contrast, similar numbers of allogeneic DCs were found in both control and NK-depleted pfp-deficient B6 mice, suggesting that perforin-dependent cytotoxicity is the main pathway of NK cell-mediated allogeneic DC killing in vivo. Unlike for allogeneic DCs, migration and survival of syngeneic B6 DCs were not affected by perforin-deficiency (not shown). We also investigated the role of IL-12R-signaling in NK cells, as IL-12 has been reported to be required for NK cell cytotoxicity in some in vivo models $^{32}$. As shown in Figure 6B and Figure S4B, NK cells in IL-12R 32 -deficient mice were as effective as in WT mice in mediating cytotoxic elimination of allogeneic DCs in vivo.

The key role played by perforin in the elimination of allogenic DC was then confirmed by confocal microscopy analysis. $\mathrm{B} 6 \mathrm{CD}^{-/-}$or $\mathrm{B} 6 \mathrm{CD}^{-/-} \mathrm{pfp}^{-/-}$double knock-out mice were co-injected as above with BALB/c (green) and B6 (red) DCs (Figure 6C and D). While allogeneic BALB/c DCs were almost absent in $\mathrm{B} 6 \mathrm{CD}^{-/-}$mice (Figure $6 \mathrm{C}$ ), they were readily detectable within the draining lymph nodes of $\mathrm{B} 6 \mathrm{CD}^{-/} \mathrm{pfp}^{-/-}$mice (Figure 6D), despite similar numbers of NK cells (Figure S5). Depletion of host NK cells by anti-NK.1.1 treatment Supprimé fully restored allogeneic DC numbers in $\mathrm{B} 6 \mathrm{CD}^{-/-}$mice (Figure $6 \mathrm{C}$ ), whereas it had no significant effect on allogeneic DC persistence in perforin-deficient B6 $\mathrm{CD}^{-/-}$mice (Figure 6D). Likewise, strong alloreactive $\mathrm{CD}^{+} \mathrm{T}$ cell priming occurred in pfp-deficient $\mathrm{B} 6 \mathrm{CD} 8-/-$ mice whether NK cells were present or not (Figure S6). To demonstrate that perforin in NK cells was indeed crucial for allogeneic DC elimination, we examined whether adoptively tranferred wild-type NK cells could influence BALB/c DCs numbers in perforin-deficient $\mathrm{CD}^{-/}$mice. Allogeneic BALB/c DC numbers were substantially reduced in lymph node sections from mice reconstituted with highly purified wild-type NK cells (Figure S7). Altogether, these data demonstrate that perforin-dependent cytotoxicity is the main pathway implicated in allogeneic DC elimination by host NK cells within lymph nodes. 
Early killing of allogeneic H-2 ${ }^{\mathrm{d}}$ DCs by host $\mathrm{NK}$ cells inhibits alloreactive $\mathrm{CD8}^{+} \mathrm{T}$ cell priming in vivo.

Since $\mathrm{CD}^{+} \mathrm{T}$ cells can clearly contribute to allogeneic DC killing in the lymph nodes ${ }^{15}$, we used so far CD8-deficient mice to focus more accurately on the mechanisms of DC Supprimé : cells killing by NK cells. To assess the significance of our findings in a situation where other MHC class I-directed pathways are operating, we first evaluated the effect of NK cells in alloreactive $\mathrm{CD}^{+} \mathrm{T}$ cell-priming. For this, $\mathrm{CD} 8$-deficient mice were reconstituted with CFSE-labelled $\mathrm{CD}^{+} \mathrm{T}$ lymphocytes from normal mice prior to allogeneic $\mathrm{DC}$ immunization. Recipient mice were depleted or not of NK cells by anti-NK1.1 mAb treatment. CFSEdilution in $\mathrm{CD}^{+} \mathrm{T}$ cells in draining lymph nodes was evaluated 4 days later. In control mice, $\mathrm{CD}^{+} \mathrm{T}$ lymphocytes that had divided and thus demonstrated lower CFSE intensity were detected in the lymph nodes draining the allogeneic DC injection site (Figure 7 A) as compared to distal lymph nodes (Figure 7B) or lymph nodes from naïve control (data not shown). Interestingly, NK cell depletion further increased the frequency of proliferating Supprimé : Interestignly $\mathrm{CD}^{+} \mathrm{T}$ cells (Figure $\left.7 \mathrm{~A}-\mathrm{D}\right)$. We next evaluated the NK cell requirement for allogeneic DC elimination in wild-type mice. Normal mice were either left untreated, depleted of NK cells, or both NK cells and $\mathrm{CD}^{+} \mathrm{T}$ lymphocytes prior to administration of differentially labelled DCs as in Figure 6. Draining lymph nodes were collected after 28 or 72 hours to determine the frequency of allogeneic BALB/c DCs by confocal microscopy. Data in Figure 7 (E and F) show that, in normal mice, NK cells have already eliminated allogeneic DCs by 28 hours, before $\mathrm{CD}^{+} \mathrm{T}$ cell-mediated killing that occured later by $48-72$ hours, in agreement with our previous work ${ }^{15}$. In conclusion, these data demonstrate that host NK cells can kill allogeneic $\mathrm{H}-2^{\mathrm{d}} \mathrm{DCs}$ in the presence of $\mathrm{CD}^{+} \mathrm{T}$ cells thereby limiting alloreactive $\mathrm{CD} 8^{+} \mathrm{T}$ cell priming in vivo. 


\section{Discussion.}

Here we report that in allotransplantation settings, host NK cells regulate alloreactive

Supprimé

$\mathrm{T}$ cell responses through direct killing of allogeneic DCs in secondary lymphoid organs. We showed that newly recruited Ly49D $\mathrm{D}^{+} \mathrm{NK}$ cells in $\mathrm{B} 6$ recipients specific for $\mathrm{H}-2 \mathrm{D}^{\mathrm{d}} \mathrm{MHC}$ class I molecules were able to kill allogeneic BALB/c $\left(\mathrm{H}-2^{\mathrm{d}}\right)$ DCs through a perforin-dependent mechanism. Our data support a model in which donor-derived DCs migrate into the draining lymph nodes where they induce $\mathrm{L}$-selectin-dependent recruitment of blood-borne NK cells. Thus, recruitment of alloreactive NK cells in graft draining lymph nodes could limit alloreactive $\mathrm{T}$ cell priming through lysis of allogeneic DCs. Indeed, in a model of CD4 $4^{+} \mathrm{T}$ cell mediated skin graft rejection, we showed that the absence of NK cell activation resulted in an Supprimé : enhanced expansion of alloreactive $\mathrm{CD}^{+} \mathrm{T}$ cells, including $\mathrm{Th} 2$ cells which probably accounted for the massive infiltrates of eosinophils found in rejected allografts. In normal Supprimé : ed mice, we finally showed that NK cells quickly eliminated allogeneic DCs within the lymph nodes draining the $\mathrm{DC}$ injection site thereby inhibiting alloreactive $\mathrm{CD} 8^{+} \mathrm{T}$ cell responses. These data, in agreement with previous works ${ }^{13,14}$, support the concept that host NK cells may suppress rather than enhance alloreactive $\mathrm{CD}^{+}$and $\mathrm{CD}^{+} \mathrm{T}$ cell responses through their capacity to rapidly kill donor derived APCs in secondary lymphoid tissues.

Indeed, besides their important function in the elimination of transformed or infected cells in the periphery, recent evidence from both human and mouse studies have documented that NK cells could also regulate adaptive immune responses by modulating DC functions or by producing polarizing cytokines such as IFN- $\gamma^{27,33-35}$. In vitro experiments have shown that human NK cells can efficiently kill autologous immature but not mature DCs, suggesting that NK cells might play an important regulatory role by selecting immunogenic mature DCs during the initiation of immune responses ${ }^{33,34}$. The situation is however different in allotransplantation settings where mature allogeneic DCs, lacking self-MHC class I, should be 
readily eliminated by host alloreactive NK cells, leading to opposite effects on the T cell responses. Indeed, donor NK alloreactivity has been exploited in bone marrow transplantation to improve clinical outcome. Alloreactive NK cells were not only able to induce more effective elimination of leukemia cells, but also to prevent graft-versus-host disease through their capacity to kill recipient DCs thereby avoiding alloreactive donor T cell priming ${ }^{36}$. Interestingly, in skin transplantation models, it has been recently shown that recipient NK cells were able to prevent the persistence of graft-derived allogeneic DCs. In this study, the presence of recipient NK cells was required to promote efficient allograft survival induced by costimulation blockade ${ }^{13}$. However, the mechanisms by which NK cells were able to eliminate allogeneic DC in situ were not examined. Our present work now shows that encounter of mature allogeneic DCs with NK cells occurs in secondary lymphoid organs leading to NK cell-mediated killing of donor-derived DCs, thereby inhibiting alloreactive T cell priming. In addition, we clearly established that the perforin-pathway is mainly involved in allogeneic DC elimination. This is in contrast with the NK-mediated killing of immature autologous DC in vivo which has been mainly attributed to TRAIL-mediated cytotoxicity rather than perforin ${ }^{37}$.

Phenotypically and functionally distinct subsets of NK cells have been described in human ${ }^{38}$ and in mouse ${ }^{29}$. It is unlikely that the immunoregulatory function of NK cells we observed in this work could be attributed to the lymph node resident $\mathrm{CD} 127^{+} \mathrm{NK}$ subset ${ }^{29}$. In mouse lymph node resident NK cells represent only $0.5 \%$ of mononuclear cells, of which only $20 \%$ are $\mathrm{CD} 127^{+29}$. However, although mouse NK cells appear to be excluded from lymph nodes under steady-state conditions, they can be recruited at high numbers into LNs draining sites of immunization or infection ${ }^{18,27,39,40}$. In a mouse model, it has been recently shown that mature DCs could promote NK cell recruitment to lymph nodes which provided an early source of IFN- $\gamma$ required for optimal Thl cell development ${ }^{27}$. In our model, we 
showed that NK cells expressing Ly49D compose the main subset implicated not only in the regulation of $\mathrm{T}$ cell expansion and polarization but also in perforin-mediated allogeneic DCkilling. Thus, the requirement for Ly49D expression together with pfp-dependent cytotoxicity pointed out to a role for $\mathrm{CD} 127^{-}$rather than $\mathrm{CD} 127^{+} \mathrm{NK}$ subset. $\mathrm{CD} 127^{-} \mathrm{Ly} 49 \mathrm{D}^{+} \mathrm{NK}$ cells are likely to be recruited from the peripheral blood into the DC-draining lymph nodes. In agreement with recent works ${ }^{18,27}$, we showed that NK cell recruitment in lymph nodes occurred through a L-selectin dependent mechanism. Indeed, preventing lymphocyte recruitment by $\mathrm{CD} 62 \mathrm{~L}$ blockade resulted in an increased persistence of incoming allogeneic DCs, demonstrating that recently recruited NK cells were implicated in the perforindependent killing of these cells.

In summary, our study has characterized the mechanisms governing the killing of allogeneic DCs by host NK cells, which results in impaired development of alloreactive T cell responses. Allogeneic $\left(\mathrm{H}-2^{\mathrm{d}}\right) \mathrm{DC}$ elimination is perforin-dependent, occcurs in draining lymph nodes and requires the recruitment of $\mathrm{CD} 127^{-} \mathrm{Ly} 49 \mathrm{D}^{+}$blood-borne NK cells. Our study, together with recent works ${ }^{13}$, suggest that alloreactive NK cells through their capacity to rapidly kill donor-derived allogeneic DCs could synergize with immunosuppressive agents to limit $\mathrm{T}$ cell alloreactivity and to improve induction of transplantation tolerance. 


\section{Acknowledgments}

The skillful assistance of the personnel of the animal facility at the Institut Fédératif de Recherche 30 (IFR30) is greatly acknowledged. We also thank C. Coureau (INSERM U563), F. Capilla (Histopathology facility, IFR30) and Sophie Allart (Cellular Imaging facility, IFR30) for their technical assistance. We wish to thank Dr S. Guerder (INSERM U563) for stimulating discussions, Dr H.R. MacDonald (Ludwig Institute for cancer research, Epalinges, Switzerland) and Dr T. Walzer (Centre d'Immunologie de Marseille-Luminy, France) for kindly providing Mel-14 monoclonal antibody and anti-NKp46 antibodies, respectively.

\section{Author's contribution statement}

Sophie Laffont designed, performed research and analyzed data. Cyril Seillet performed research and analyzed data. Jérôme D. Coudert designed research and analyzed data. John Ortaldo provided reagents and reviewed the data and the manuscript. Jean-Charles Guéry designed research, analyzed data and wrote the paper with input from the co-authors. The authors declare no competing financial interests. 


\section{References}

1. Trinchieri G. Biology of natural killer cells. Adv Immunol. 1989;47:187-376.

2. Raulet $\mathrm{DH}$, Vance RE, McMahon $\mathrm{CW}$. Regulation of the natural killer cell receptor repertoire. Annu rev Immunol. 2001;19:291-330.

3. Lanier LL. NK cell recognition. Annu Rev Immunol. 2005;23:225-274.

4. Ljunggren HG, Karre K. In search of the 'missing self': MHC molecules and NK cell recognition. Immunol Today. 1990;11:237-244.

5. Manilay JO, Sykes M. Natural killer cells and their role in graft rejection. Curr Opin Immunol. 1998;10:532-538.

6. Kitchens WH, Uehara S, Chase CM, Colvin RB, Russell PS, Madsen JC. The changing role of natural killer cells in solid organ rejection and tolerance. Transplantation. 2006;81:811-817.

7. Heidecke CD, Araujo JL, Kupiec-Weglinski JW, et al. Lack of evidence for an active role for natural killer cells in acute rejection of organ allografts. Transplantation. $1985 ; 40: 441-444$.

8. Zijlstra M, Auchincloss H, Jr., Loring JM, Chase CM, Russell PS, Jaenisch R. Skin graft rejection by beta 2-microglobulin-deficient mice. J Exp Med. 1992;175:885-893.

9. Maier S, Tertilt $\mathrm{C}$, Chambron $\mathrm{N}$, et al. Inhibition of natural killer cells results in acceptance of cardiac allografts in CD28-/- mice. Nat Med. 2001;7:557-562.

10. Uehara $\mathrm{S}$, Chase $\mathrm{CM}$, Kitchens $\mathrm{WH}$, et al. NK cells can trigger allograft vasculopathy: the role of hybrid resistance in solid organ allografts. J Immunol. 2005;175:3424-3430.

11. McNerney ME, Lee KM, Zhou P, et al. Role of natural killer cell subsets in cardiac allograft rejection. Am J Transplant. 2006;6:505-513.

12. Beilke JN, Kuhl NR, Van Kaer L, Gill RG. NK cells promote islet allograft tolerance via a perforin-dependent mechanism. Nat Med. 2005;11:1059-1065. 
13. Yu G, Xu X, Vu MD, Kilpatrick ED, Li XC. NK cells promote transplant tolerance by killing donor antigen-presenting cells. J Exp Med. 2006;203:1851-1858.

14. Coudert JD, Coureau C, Guery JC. Preventing NK cell activation by donor dendritic cells enhances allospecific CD4 $\mathrm{T}$ cell priming and promotes Th type 2 responses to transplantation antigens. J Immunol. 2002;169:2979-2987.

15. Laffont S, Coudert JD, Garidou L, et al. CD8+ T-cell-mediated killing of donor dendritic cells prevents alloreactive T helper type-2 responses in vivo. Blood. 2006;108:22572264.

16. Lutz MB, Kukutsch N, Ogilvie ALJ, et al. An advanced culture method for generating large quantities of highly pure dendritic cells from mouse bone marrow. J Immunol Meth. 1999;223:77-92.

17. Foucras G, Coudert JD, Coureau C, Guery JC. Dendritic cells prime in vivo alloreactive CD4 T lymphocytes toward type 2 cytokine- and TGF-beta-producing cells in the absence of CD8 T cell activation. J Immunol. 2000;165:4994-5003.

18. Bajenoff M, Breart B, Huang AY, et al. Natural killer cell behavior in lymph nodes revealed by static and real-time imaging. J Exp Med. 2006.

19. Lechler R, Ng WF, Steinman RM. Dendritic cells in transplantation--friend or foe? Immunity. 2001;14:357-368.

20. Raziuddin A, Longo DL, Mason L, Ortaldo JR, Bennett M, Murphy WJ. Differential effects of the rejection of bone marrow allografts by the depletion of activating versus inhibiting Ly-49 natural killer cell subsets. J Immunol. 1998;160:87-94.

21. George TC, Mason LH, Ortaldo JR, Kumar V, Bennett M. Positive recognition of MHC class I molecules by the Ly49D receptor of murine NK cells. J Immunol. 1999;162:2035-2043. 
22. Mason LH, Willette-Brown J, Anderson SK, et al. Receptor glycosylation regulates Ly-49 binding to MHC class I. J Immunol. 2003;171:4235-4242.

23. Ortaldo JR, Winkler-Pickett R, Mason AT, Mason LH. The Ly-49 family: regulation of cytotoxicity and cytokine production in murine CD3+ cells. J Immunol. 1998;160:11581165 .

24. Ortaldo JR, Winkler-Pickett R, Wiegand G. Activating Ly-49D NK receptors: expression and function in relation to ontogeny and Ly-49 inhibitor receptors. J Leukoc Biol. 2000;68:748-756.

25. Smith KM, Wu J, Bakker AB, Phillips JH, Lanier LL. Ly-49D and Ly-49H associate with mouse DAP12 and form activating receptors. J Immunol. 1998;161:7-10.

26. Walzer T, Blery $\mathrm{M}$, Chaix $\mathrm{J}$, et al. Identification, activation, and selective in vivo ablation of mouse NK cells via NKp46. Proc Natl Acad Sci U S A. 2007;104:3384-3389.

27. Martin-Fontecha A, Thomsen LL, Brett S, et al. Induced recruitment of NK cells to lymph nodes provides IFN-gamma for T(H)1 priming. Nat Immunol. 2004;5:1260-1265.

28. Chen S, Kawashima H, Lowe JB, Lanier LL, Fukuda M. Suppression of tumor formation in lymph nodes by L-selectin-mediated natural killer cell recruitment. J Exp Med. $2005 ; 202: 1679-1689$.

29. Vosshenrich CA, Garcia-Ojeda ME, Samson-Villeger SI, et al. A thymic pathway of mouse natural killer cell development characterized by expression of GATA-3 and CD127. Nat Immunol. 2006;7:1217-1224.

30. Russell JH, Ley TJ. Lymphocyte-mediated cytotoxicity. Annu Rev Immunol. $2002 ; 20: 323-370$.

31. Guarda G, Hons M, Soriano SF, et al. L-selectin-negative CCR7- effector and memory CD8+ T cells enter reactive lymph nodes and kill dendritic cells. Nat Immunol. 2007;8:743752. 
32. Schleicher U, Liese J, Knippertz I, et al. NK cell activation in visceral leishmaniasis requires TLR9, myeloid DCs, and IL-12, but is independent of plasmacytoid DCs. J Exp Med. 2007;204:893-906.

33. Raulet DH. Interplay of natural killer cells and their receptors with the adaptive immune response. Nat Immunol. 2004;5:996-1002.

34. Moretta L, Ferlazzo G, Bottino C, et al. Effector and regulatory events during natural killer-dendritic cell interactions. Immunol Rev. 2006;214:219-228.

35. Cooper MA, Fehniger TA, Fuchs A, Colonna M, Caligiuri MA. NK cell and DC interactions. Trends Immunol. 2004;25:47-52.

36. Ruggeri L, Capanni M, Urbani E, et al. Effectiveness of donor natural killer cell alloreactivity in mismatched hematopoietic transplants. Science. 2002;295:2097-2100.

37. Hayakawa $\mathrm{Y}$, Screpanti V, Yagita $\mathrm{H}$, et al. NK cell TRAIL eliminates immature dendritic cells in vivo and limits dendritic cell vaccination efficacy. J Immunol. 2004;172:123-129.

38. Ferlazzo G, Munz C. NK cell compartments and their activation by dendritic cells. J Immunol. 2004;172:1333-1339.

39. Fehniger TA, Cooper MA, Nuovo GJ, et al. CD56bright natural killer cells are present in human lymph nodes and are activated by $\mathrm{T}$ cell-derived $\mathrm{IL}-2$ : a potential new link between adaptive and innate immunity. Blood. 2003;101:3052-3057.

40. Ferlazzo G, Pack M, Thomas D, et al. Distinct roles of IL-12 and IL-15 in human natural killer cell activation by dendritic cells from secondary lymphoid organs. Proc Natl Acad Sci U S A. 2004;101:16606-16611. 
Figure legends

Figure 1. In absence of NK cell activation, allogeneic skin grafting induces strong alloreactive $\mathrm{CD4}^{+} \mathrm{T}$-cell responses associated with $\mathrm{Th} 2$ cell development and massive eosinophil recruitment. (A, B, C) $\mathrm{B} 6 \mathrm{CD}^{-/-}$mice treated or not with anti-NK1.1 PK136 $\mathrm{mAb}$, received a skin graft from allogeneic BALB/c mice. Eight days after grafting, draining lymph nodes were harvested. Lymph nodes from naïve mice were taken as control. Purified $\mathrm{CD}^{+} \mathrm{T}$ cells were cultured $\left(2 \times 10^{5}\right.$ cells/well $)$ in the presence of irradiated allogeneic BALB/c splenocytes $\left(1 \times 10^{5}\right.$ cells/well) for 72 hours. (A) $\mathrm{CD}^{+} \mathrm{T}$-cell proliferation was evaluated by ${ }^{3} \mathrm{H}-\mathrm{TdR}$ incorporation. Background proliferation were below $500 \mathrm{cpm}$. (B) IFN$\gamma$ and (C) IL-4 productions were measured by ELISA in 72-hour culture supernatants. Results are expressed as mean $\pm \mathrm{SEM}$ of 5 mice per group. (D) B6 $\mathrm{CD}^{-/-}$mice, treated or not with anti-NK1.1, received a skin graft from syngeneic B6, semi-allogeneic CB6F1 or fully allogeneic BALB/c mice. At the day of graft rejection (day 10-12), transplanted skins were harvested. Skin histological analyses were performed and the percentage of eosinophils among total mononuclear infiltrating cells was evaluated as described in "Materials and methods" (3-5 mice per group). Data are from one representative experiment of at least two performed. $* P<0.05 ; * * P<0.01 ;$ N.S., not significant.

Figure 2. $\mathrm{Ly}_{49 D^{+}} \mathrm{NK}$ cells regulate alloreactive CD4 $\mathrm{T}$ cell priming and polarization in response to allogeneic $\mathrm{H}^{\mathrm{d}}{ }^{\mathrm{d}}$ DCs. (A) $\mathrm{B} 6 \mathrm{CD}^{-/-}$mice, treated or not with anti-NK1.1 PK136 $\mathrm{mAb}$ or anti-Ly49A/D 12A8 mAb, were injected s.c. with allogeneic BALB/c DCs. Six days after immunization, $\mathrm{CD}^{+} \mathrm{T}$ cells were purified from draining lymph nodes, and restimulated $\left(2 \times 10^{5}\right.$ cells/well) with irradiated allogeneic BALB/c splenocytes for 72 hours to measure proliferation and cytokine production. Results are expressed as mean \pm SEM of 3 mice per 
group. Data are from one representative experiment of three performed. (B) To evaluate the frequency of IL-4-producing cells, purified $\mathrm{CD}^{+} \mathrm{T}$ cells were cultured for 8 hours with $\mathrm{T}$ cell-depleted BALB/c splenocytes in the presence of anti-CD28 mAb. Intracytoplasmic staining for IL-4 was then performed as described in "Materials and methods". Results are expressed as percentage of $\mathrm{CD} 69^{\mathrm{pos}} \mathrm{CD} 4^{\mathrm{pos}} \mathrm{T}$ cells producing IL-4 (mean $\pm \mathrm{SEM}$ of 3 mice per group). (C, D) B6 CD8 ${ }^{-/}$mice, treated or not with anti-NK1.1 PK136 mAb or anti-Ly49D 4E5 mAb, were injected s.c. with DCs derived from either WT BALB/c mouse (C) or $\beta 2 \mathrm{~m}^{-/-}$ BALB/c mouse (D). Six days after immunization, $\mathrm{CD}^{+} \mathrm{T}$ cells were purified from draining lymph nodes, and restimulated $\left(2 \times 10^{5}\right.$ cells/well) with irradiated allogeneic BALB/c splenocytes for 72 hours to measure proliferation and cytokine production. Results are expressed as mean \pm SEM of 3 mice per group. Background proliferation were below 1500 cpm. Data are representative of at least two experiments performed.

Figure 3. Increased recruitment and activation of host NK cells in lymph nodes following allogeneic DC immunization. $\mathrm{B} 6 \mathrm{CD}^{-/-}$mice were left untreated (-) or injected with either syngeneic B6 DCs or allogeneic BALB/c DCs. 24 hours after immunization, draining lymph nodes were harvested and the percentage of TCR $\beta^{\text {neg }} \mathrm{NK} 1.1^{\text {pos }}$ cells was determined (A) as well as the percentage of NK cells (TCR $\beta^{\text {neg }} \mathrm{NK} 1.1^{\mathrm{pos}} \mathrm{DX} 5^{\mathrm{pos}}$ ) expressing CD69 (B) and CD11b (C). The frequency of CD6 $9^{\text {pos }} \mathrm{NK}$ cells $\left(\mathrm{TCR} \beta^{\text {neg }} \mathrm{NK} 1.1^{\mathrm{pos}}\right)$ producing IFN- $\gamma$ was evaluated by ex-vivo intracytoplasmic staining without prior stimulation as described in "Materials and methods" (D). Results are expressed as mean \pm SEM of 4 to 5 mice per group. $* P<0.05 ; * * P<0.01 ;$ N.S., not significant. Data are from one representative experiment of three performed.

Figure 4. The persistence of donor-derived DCs in lymph nodes is impaired in the 
presence of host $\mathrm{Ly}_{49 \mathrm{D}^{+}} \mathrm{NK}$ cells. (A, B) B6 $\mathrm{CD}^{-/-}$mice, treated or not with anti-NK1.1 PK136 mAb, were injected with CFSE ${ }^{\text {low }}$-labeled syngeneic B6 DCs and CFSE ${ }^{\text {high }}$-labeled allogeneic BALB/c DCs. Draining lymph nodes were harvested at indicated times after immunization and analyzed for the presence of CFSE-labeled cells. Cells were gated on CD11c ${ }^{\text {pos }}$, MHC II Iigh $^{\text {and } C F S E}{ }^{\text {pos }}$ cells. (A) Representative CFSE profiles of injected DCs obtained at 48 hours from untreated or PK136-treated mice. (A, B) Numbers in dot plots and histograms indicate the percentages of allogeneic BALB/c CFSE ${ }^{\text {high }}$ cells normalized to control syngeneic B6 $\mathrm{CFSE}^{\text {low }}$ cells [(\%BALB/c DCs : \%B6 DCs) x 100]. (C) B6 $\mathrm{CD}^{-/ /}$mice were treated, or not, with anti-NK1.1 PK136 mAb or anti-Ly49D 4E5 mAb, and injected as in (A) with a mixture of $\mathrm{CFSE}^{\text {low }}$-B6 DCs and $\mathrm{CFSE}^{\text {high }}$-BALB/c DCs. 48 hours after immunization, the presence of CFSE positive cells was analyzed in the draining lymph nodes and the percentage of $\mathrm{CFSE}^{\text {high }} \mathrm{BALB} / \mathrm{c}$ cells among control $\mathrm{CFSE}^{\text {low }} \mathrm{B} 6$ cells was determined. Results are expressed as mean \pm SEM of 3 to 4 mice per group. (D) B6 $\mathrm{CD}^{-/-}$ mice treated or not with PK136 were injected with 1 or $2 \times 10^{6}$ CMTMR-labeled BALB/c DCs. 48 hours after immunization, draining lymph nodes were harvested, prepared as described in "Materials and methods", and stained with anti-B220 and anti-PNAd mAbs (blue). Lymph nodes sections were then analyzed by confocal microscopy and the numbers of red DCs per lymph node were evaluated. Results are expressed as mean \pm SEM of four lymph nodes per group (two mice/group). (E, F) B6 CD8 ${ }^{-/-}$mice were treated or not with PK136 as indicated before immunization with DCs. (E) Mice were immunized with CMTMR-labeled BALB/c DCs (red). Frozen sections of lymph nodes at 48 hours were stained with goat antNKp46 antibodies and then donkey anti-goat Alexa488 antibodies. Numbers of NK cells and $\mathrm{BALB} / \mathrm{c}$ DCs per section were counted and results expressed as mean $\pm \mathrm{SEM}$ of four to six lymph nodes per group. In panels (F), mice were injected with CFSE-labeled BALB/c DCs (green) and CMTMR-labeled B6 DCs (red). Draining lymph nodes were removed at indicated 
times after immunization to evaluate the kinetics of allogeneic DC appearance. Lymph node sections were then stained with anti-B220 and anti-PNAd mAbs (blue). Representative tissue sections from untreated or PK136-treated mouse lymph nodes harvested at 48 hours after injection are depicted. Histograms indicate the percentage of CFSE BALB/c cells among control CMTMR B6 cells. Results are expressed as mean \pm SEM of individual lymph nodes (2-3 mice per group). $* P<0.05 ; * * P<0.01 ;$ N.S., not significant. Data are representative of at least two to three experiments performed.

Figure 5. Recently recruited NK cells are responsible for allogeneic DC killing. (A, B, C) $\mathrm{B} 6 \mathrm{CD}^{-/-}$mice, treated or not with anti-CD62L Mel-14 mAb, were immunized with $\mathrm{CFSE}^{\text {high }}$ syngeneic B6 DCs and $\mathrm{CFSE}^{\text {low }}$ allogeneic BALB/c DCs. 48 hours after injection, draining lymph nodes were removed and analyzed for the presence of NK cells and CFSE DCs (CD11 $c^{\text {pos }} \mathrm{MHC}^{\mathrm{h}}{ }^{\text {high }} \mathrm{CFSE}^{\mathrm{pos}}$ cells). (A) Absolute numbers of NK cells $\left(\mathrm{TCR} \beta^{\text {neg }} \mathrm{NK} 1.1^{\mathrm{pos}}\right.$ ) recovered from lymph node are indicated. (B) Expression of CD127 and Ly49D on NK cells $\left(\mathrm{TCR} \beta^{\text {neg }} \mathrm{NK} 1.1^{\mathrm{pos}}\right)$. (C) Representative CFSE profiles of injected DCs from control, Mel-14or PK136-treated mouse lymph nodes are shown. Numbers indicate the percentage of $\mathrm{CFSE}^{\text {low }}$ BALB/c DCs among control CFSE ${ }^{\text {high }}$ B6 DCs. A representative experiment of three is shown.

Figure 6. Perforin-mediated killing is critical for the elimination of allogeneic DCs by host NK cells in vivo. (A) B6 WT, B6 $\mathrm{pfp}^{-/-}$or (B) $\mathrm{IL}-12 \mathrm{R} \beta 2^{-/-}$mice, all CD8-depleted, were injected or not with anti-NK1.1 PK136 mAb and then immunized with equal numbers of CFSE $^{\text {low }}-$ B6 DCs and CFSE ${ }^{\text {high }}$-BALB/c DCs. (A) Results are expressed as mean \pm SEM of 3 mice per group and are from one representative experiment of four performed. (B) Results are expressed as mean $\pm \mathrm{SEM}$ of 4 mice per group. (C) $\mathrm{B}_{\mathrm{CD}} 8^{-/}$and $\mathrm{CD}^{-/ /} \mathrm{pfp}^{-/-}$(D) mice 
were injected with equal numbers of CFSE-labeled BALB/c DCs (green) and CMTMRlabeled B6 DCs (red). 48 hours after immunization draining lymph nodes were harvested and prepared for confocal microscopy analysis. Lymph node sections were stained anti-B220 and anti-PNAd mAbs (blue). Results are expressed as the percentage of CFSE BALB/c DCs among control CMTMR B6 DCs. Data were pooled from two independent experiments. Results are expressed as mean \pm SEM of individual lymph nodes (4-5 mice per group). $* P$ $<0.05 ; * * P<0.01 ;$ N.S., not significant.

Figure 7: Host NK cells inhibit alloreactive $\mathrm{CDB}^{+} \mathrm{T}$ cell priming in vivo through their capacity to rapidly eliminate allogeneic $\mathbf{H}-2^{d}$ DCs in draining lymph nodes. (A, B) B6 $\mathrm{CD}^{-/-}$mice, treated or not with anti-NK1.1 PK136 mAb, were injected i.v. with $10^{7} \mathrm{CFSE}-$ labelled $\mathrm{CD}^{+} \mathrm{T}$ lymphocytes. Mice were then immunized with allogeneic BALB/c DCs $\left(10^{6} /\right.$ mouse) one day after passive $\mathrm{CD}^{+} \mathrm{T}$ cell transfert. Four days after immunization, CFSE dilution in $\mathrm{TCR} \beta^{+} \mathrm{CD} 8^{+} \mathrm{T}$ cells was analyzed in popliteal (proximal) or inguineal (distal) lymph node cells by flow cytometry (A). Panels $\mathrm{C}$ and $\mathrm{D}$ show the percentage of $\mathrm{CD} 8^{+} \mathrm{T}$ cells (C) and CFSE low $\mathrm{CD}^{+} \mathrm{T}$ cells (D) among total popliteal lymph node cells from individual mice (3-4 per group). Data are representative of three experiments performed. In panels $E$ and F, normal C57BL/6 mice were injected with anti-NK1.1 PK136 mAb alone or together with anti-CD8 depleting $\mathrm{mAb}$ as indicated. Mice were immunized with a mixture of CFSE-labeled BALB/c DCs (green) and CMTMR-labeled B6 DCs (red) as in Figure 6. Lymph nodes were collected at 28 hours (E) or 72 hours (F) and processed for confocal microscopy analysis as in Figure 6. Histograms indicate the percentage of CFSE BALB/c DCs among control CMTMR B6 DCs. Results are expressed as mean \pm SEM of individual lymph nodes (2-3 mice per group) and are representative of two experiments performed. 
Figures

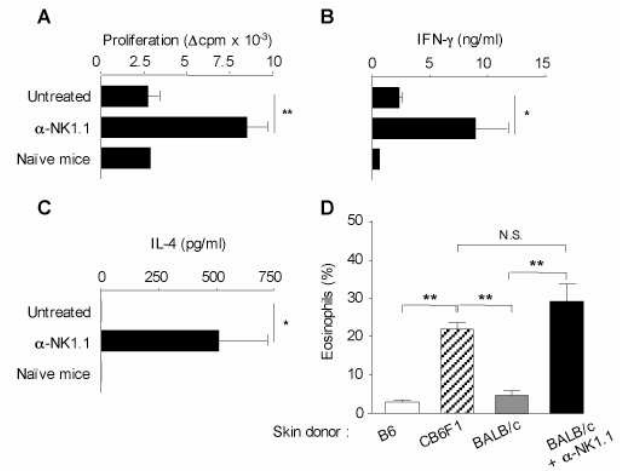

Laffont et al. Figure 1 
A

$=(-)$
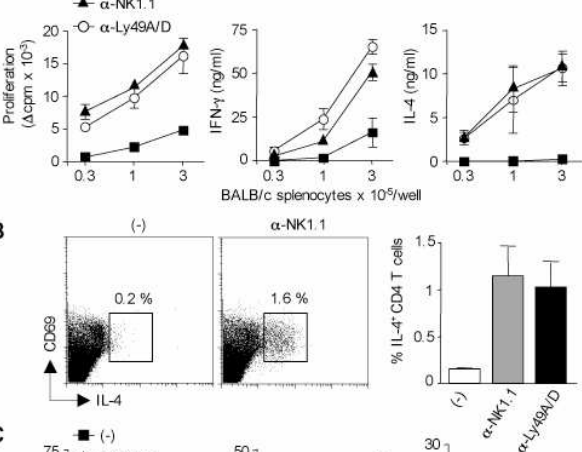

C $75-(-)$

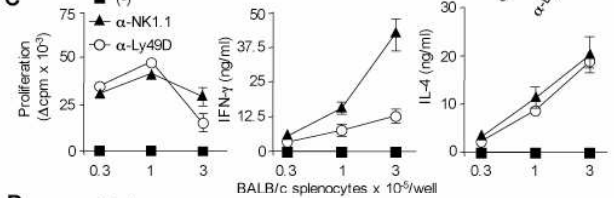

D $=(-)$

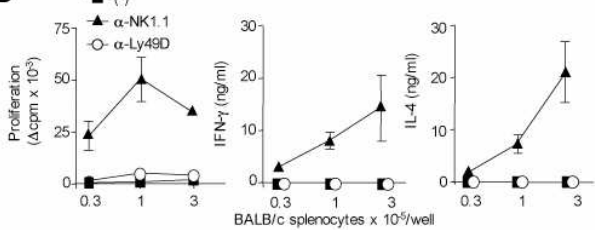

Laffont et al. Figure 2. 


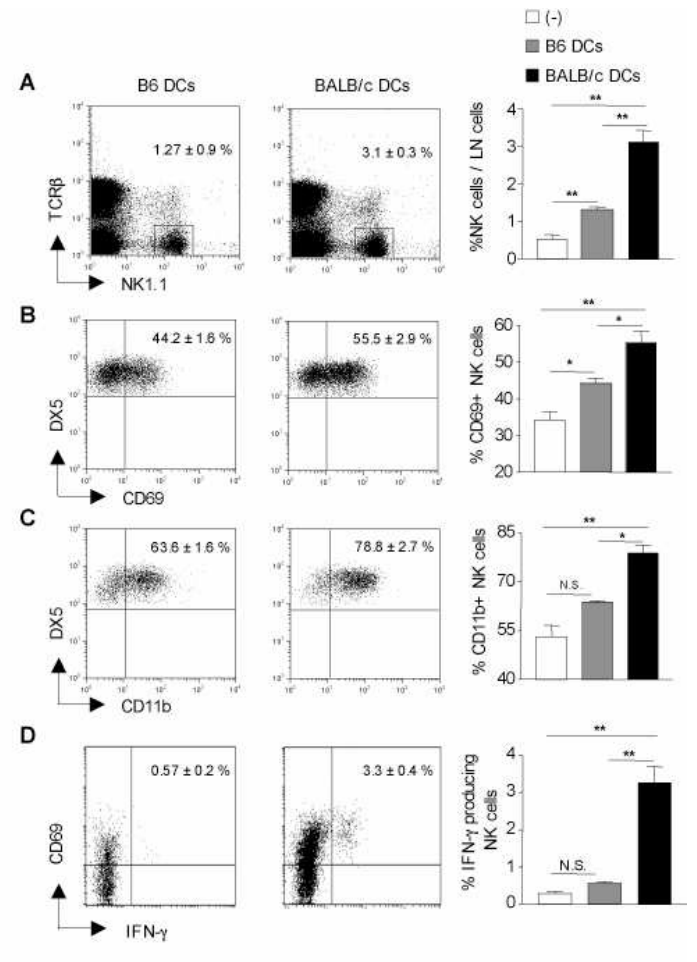

Laffont et al. Figure 3. 
A

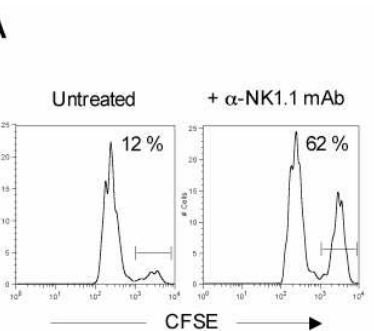

D
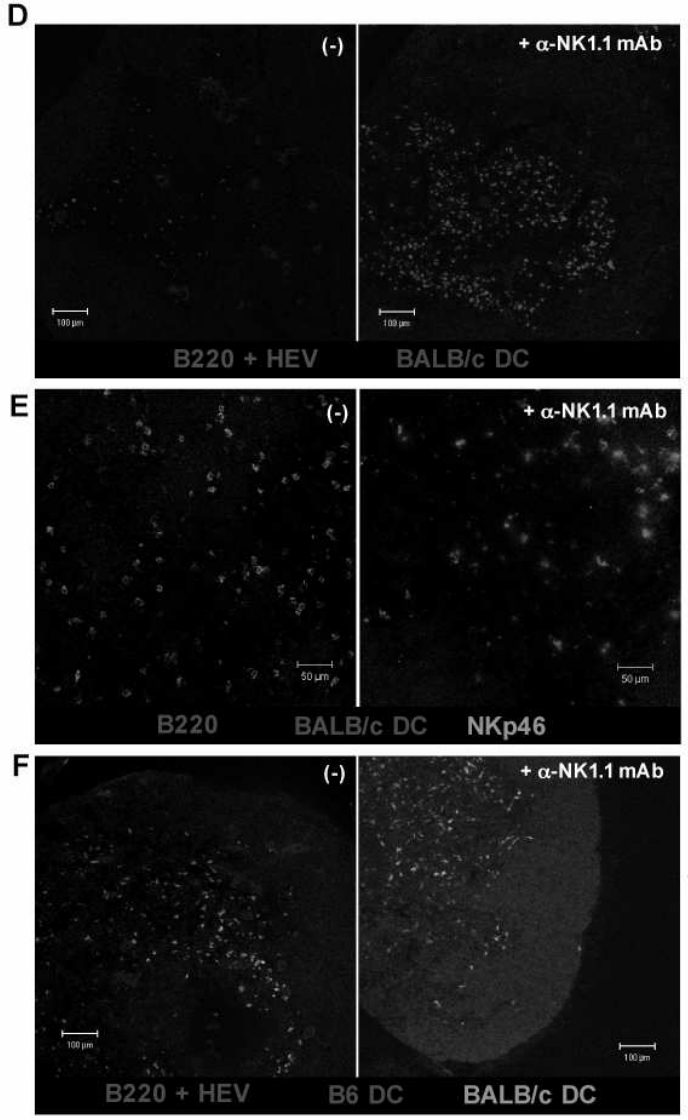

Laffont et al. Figure 4.
C $\quad \square(-) \quad \begin{aligned} & (-) \\ & +\alpha \text {-NK1 } 11 \text { mAb } \\ & \\ & +\alpha-L y 49 D \text { mAb }\end{aligned}$

30

- $+\alpha-$ Ly $49 \mathrm{D}$ mAb

120

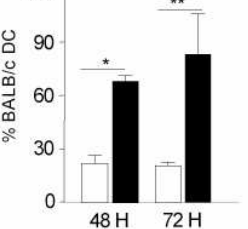

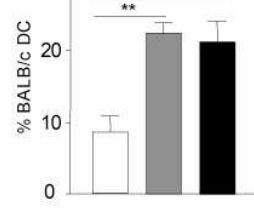

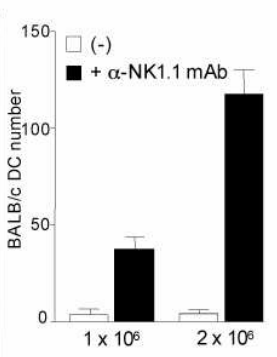

$\square(-)$

- $+\alpha-\mathrm{NK} 1.1 \mathrm{mAb}$

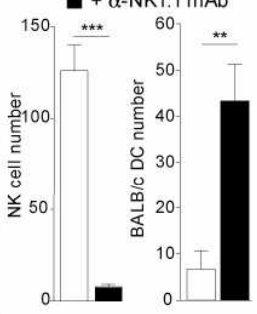

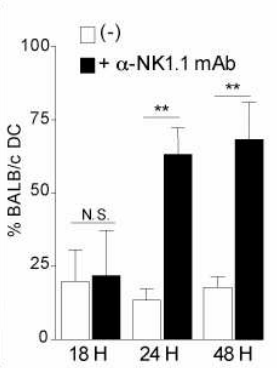



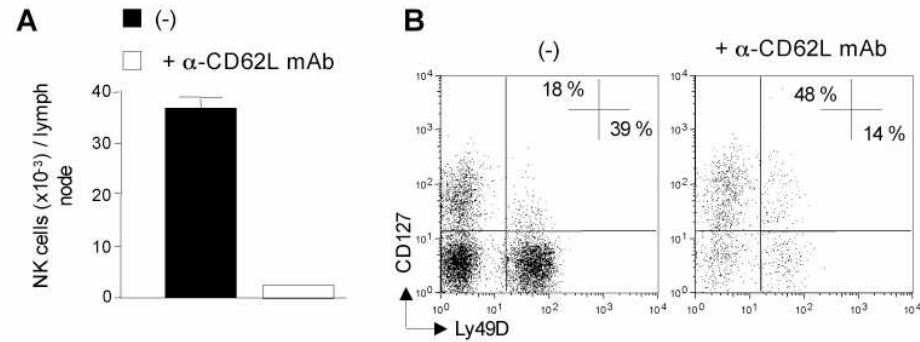

C

$(-)$

$+\alpha-C D 62 L$ mAb

$+\alpha-N K 1.1 \mathrm{mAb}$

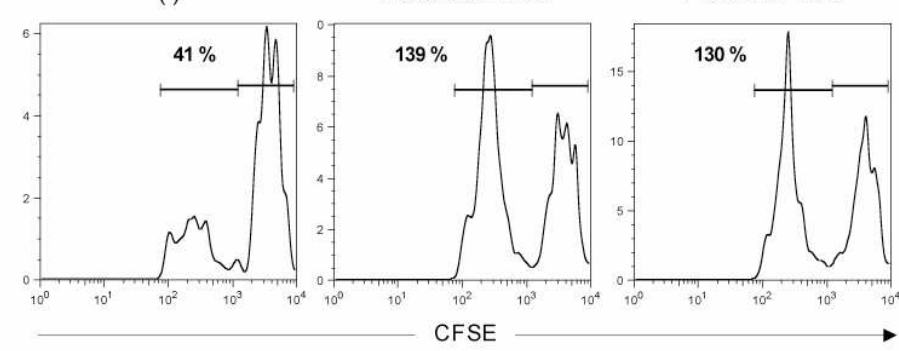

Laffont et al. Figure 5. 


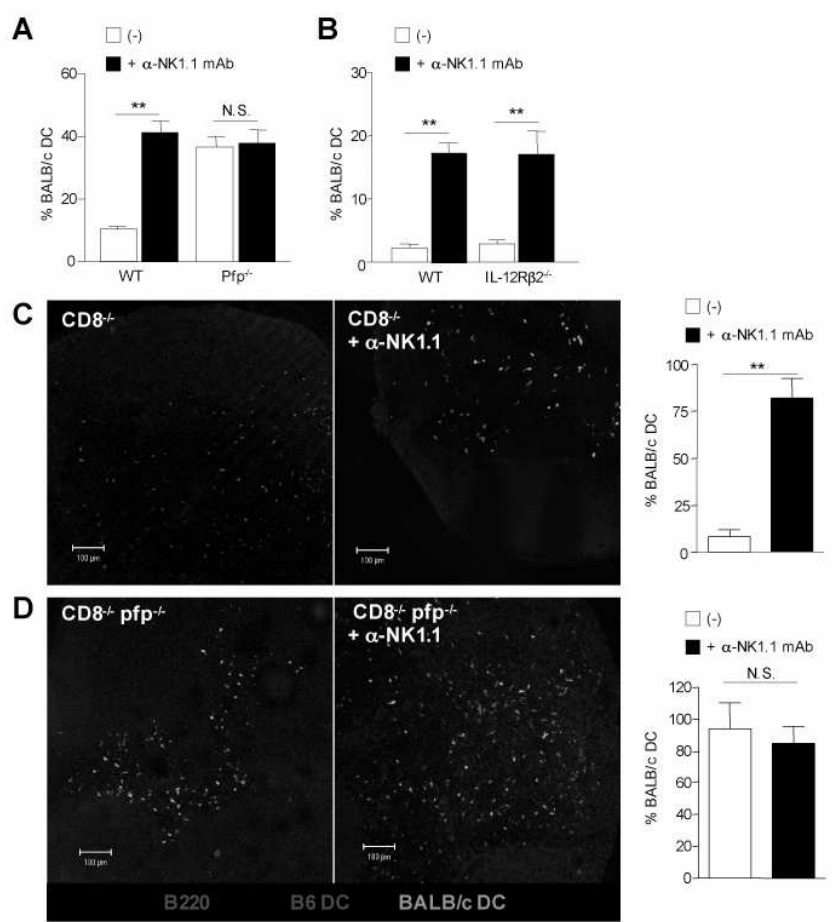

Laffont et al. Figure 6. 


\section{A Proximal lymph node}

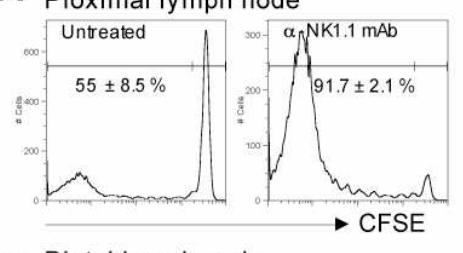

B Distal lymph node

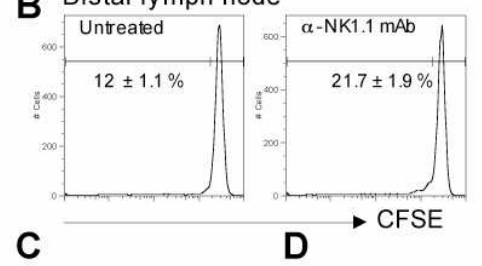

C

D

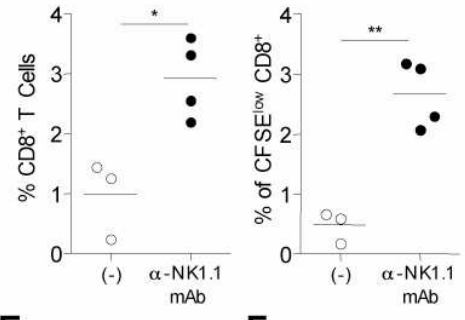

E

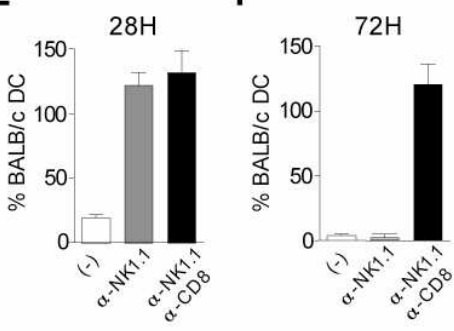

Laf font et al. Figure 7 . 